\title{
PERWUJUDAN INTERAKSI SOSIAL DALAM POLA PERMUKIMAN DI KAMPUNG PANGGUNG KOTA MALANG
}

\author{
Sarah Safirah, Wara Indira Rukmi, Chairul Maulidi \\ Jurusan Perencanaan Wilayah dan Kota Fakultas Teknik Universitas Brawijaya \\ Jalan Mayjen Haryono 167 Malang 65145 -Telp (0341)567886 \\ Email: sarahsfrh33@gmail.com
}

\begin{abstract}
ABSTRAK
Perkembangan permukiman tradisional yang berada pada tengah Kota Malang kondisinya semakin tersudut dan terdesak dikarenakan oleh perkembangan kota. Permukiman tradisional sendiri sebenarnya merupakan aset kawasan kota yang dapat memberikan ciri kota, tatanan lingkungan binaan, ciri aktifitas sosial budaya masyarakatnya, yang merupakan manifestasi nilai sosial budaya masyarakat. Hal tersebut menyebabkan perubahan interaksi sosial dalam pembentukan pola permukimannya(Rapoport,1969). Permasalahan yang terjadi pada kampung dan interaksi sisalamnya menunjukkan perlu adanya kajian lebih lanjut. Oleh karena itu, dibutuhkan adanya penelitian untuk mengidentifikasi dan menganalisis pola permukiman serta perwujudan interaksi sosial dalam pola permukiman kampung yang terdapat pada Kampung Panggung Kota Malang. Metode yang dilakukan untuk mengidentifikasi bagaimana karakteristik pola permukiman dan mengidentifikasi interaksi sosial yang terdapat didalamnya menggunakan teknik metode analisis deskriptif berupa analisis sinkronik/diakronik, analisis behaviour, serta analisis family tree. Hasil identifikasi karakteristik menunjukkan bahwa interaksi sosial dapat terbentuk berdasarkan hubungan kekerabatan tanpa dibatasi oleh pola permukiman, selain itu pola permukiman sendri juga dapat membentuk interaks sosial. Selain itu interaksi sosial yang ditemukan dapat dipengaruhi oleh perubahan fungsi bangunan yang dapat berupa perubahan secara positif maupun konflik.
\end{abstract}

Kata Kunci : Kota-Malang, Kampung-Tradisional, Interaksi-Sosial.

\begin{abstract}
The development of traditional settlements located in the middle of Malang, the condition is increasingly cornered and pressed due to the development of the city. Traditional settlements themselves are actually assets of urban areas that can give a characteristic of the city, the built environment, characteristic of the socio-cultural activities of the community, which is a manifestation of the socio-cultural values of the community. This causes changes in social interactions in the formation of settlement patterns (Rapoport, 1969). The problems that occur in the village and their interactions show that there is a need for further studies. Therefore, research is needed to identify and analyze settlement patterns and the realization of social interactions in the village settlement patterns found in Malang City Stage Village. The method is carried out to identify the characteristics of settlement patterns and identify the social interactions contained therein using descriptive analysis method techniques in the form of synchronous / diachronic analysis, behavior analysis, and family tree analysis. The results of the identification of characteristics indicate that social interactions can be formed based on kinship relationships without being limited by settlement patterns, besides that the pattern of residential settlements can also form social interactions. In addition, social interactions found can be influenced by changes in building functions that can be either positive changes or conflicts.
\end{abstract}

Keywords: Malang-City, Traditional-Kampoeng, Social-Interaction

\section{PENDAHULUAN}

Pada saat ini wajah kota Malang sudah banyak berubah, contohnya seperti asset kota berupa bangunan, permukiman atau objekobjek yang merupakan tradisi kekayaan lokal, makin banyak yang mengalami perubahan, berganti dan bercampur dengan bangunanbangunan baru. Perubahan bangunan dengan wajah yang sangat beragam cenderung kurang menunjukkan identitas dari Kota Malang sendiri. Sementara kesadaran pemerintah atas adanya budaya dan tradisi lokal ini hanya terlihat pada beberapa lokasi di Kota Malang seperti Jalan Ijen, Alun-Alun Tugu, Kawasan Kayutangan atau yang lainnya, sedangkan pada permukiman tradisional yang berada dibalik jalan besar yang sebenarnya merupakan tempat bermukim warga Malang asli tidak terlihat oleh pemerintah. Padahal mereka adalah kekayaan lokal yang sesungguhnya yang apabila lebih digali dan dilestarikan diharapkan dapat memberikan warna tersendiri dengan segala tradisi dan budayannya.

Perkembangan permukiman tradisional yang ada di Kota malang, terlebih pada 
permukiman yang berada di tengah kota kondisinya semakin tersudut dan terdesak dikarenakan oleh perkembangan kota. Padahal sebenarnya permukiman tradisional yang berada di pusat kota tersebut adalah merupakan asset kawasan kota yang dapat memberikan ciri kota, tatanan lingkungan binaan, ciri aktivitas sosial budaya masyarakatnya, atau dengan kata lain merupakan manifestasi nilai-nilai sosial budaya masyarakat (Rapoport,1969). Seperti yang diungkapkan oleh Miarsono dalam Budihardjo (1999) bahwa kawasan tradisional merupakan salah satu bagian penting bagi pertumbuhan suatu kota, kawasan ini disebut sebagai bayangan kota, yang mempunyai nilai sejarah dan ekonomi untuk pengembangan kota. Selain itu keberadaan manusia baik sebagai individu maupun sebagai kelompok tidak dapat hidup sendiri tanpa kehadiran orang atau kelompok lain. Sehingga dalam satu kawasan tradisional pasti memiliki budaya atau adat istiadat yang dijunjung didalam lokasi tersebut. Pada masa kini, perubahan konsep budaya pada suatu kelompok kawasan tradisional sudah mulai luntur karena tercampur dengan budaya lain, karena adanya perbedaan budaya dan kepercayaan di suatu pihak, namun di pohak lain kelompok tersebut harus hidup saling berhubungan satu dengan yang lainnya untuk membentuk suatu masyarakat baru kelompok tersebut harus saling menyesuaikan diri melalui interaksi sosial.

Kampung Panggung merupakan salah satu kampung tua yang ada di Kota Malang. Kampung ini dapat dikatakan sebagai kampung yang unik karena merupakan salah satu permukiman tradisional di tengah Kota Malang yang mencobat tetap bertahan di tengah desakan perkembangan kota. Pada kampung ini masih banyak diterapkan aturan-aturan Jawa dalam kehidupan sosial dan keseharinannya dikarenakan penduduk yang mendominasi Kampung Candi Panggung adalah etnis Jawa. Adat atau tradisi yang ada di Kampung Candi Panggung masih cukup bertahan kuat hingga sekarang, sebagai contoh berupa tradisi selamatan yang masih melekat dan bertahan hingga sekatang selamatan bersih desa bulan Sura lengkap dengan tanggapan kuda lumping yang diadakan di area pepunden desa. Hal itu masih dilakukan dengan rutin setiap saat-saat yang telah ditentukan oleh sesepuh desa/kampung. Beberapa potensi fisik lain yang bisa dikategorikan sebagai bagian dari kekhasan lokal adalah adanya elemen bangunan seperti terdapatnya pawonan (kompor tradisional) yang masih difungsikan hingga sekarang.

Sistem kekerabatan yang masih kental, dimungkinkan juga karena kondisi permukiman yang masih cenderung homogen, yang jika ditelusuri lebih jauh ternyata merupakan rangkaian kekerabatan. Keluarga di Kampung Candi Panggung masih menganut nilai seperti keluarga Jawa pada umumnya, sehingga interaksi sosial antara individu satu sama lain ataupun antara kelompok satu dengan yang lainnya sangat erat. Namun karena adanya pada saat ini sudah mulai terjadi pergeseran budaya, diakibatkan oleh banyaknya penduduk luar Kampung yang masuk, sehingga mulai hilangnya penerapan budaya pada seluruh masyarakat Kampung. Seperti yang disebutkan oleh Mulyani, bahwa hilangnya kekhasan lokal dan gaya hidup masyarakat, yang didasari oleh berbagai macam faktor dan juga terjadinya penerapan adat dari budaya akibat adanya perkembangan kota. Selain terjadi pergeseran budaya, pada Kampung Panggun juga terjadi perubahan pola perilaku masyarakat yang akhirnya mempengaruhi pola permukiman. Sehingga penelitian ini ditujukan untuk meneliti perwujudan interaksi sosial dalam pola permukiman yang ada pada Kampung Panggung Kota Malang.

\section{METODE PENELITIAN}

Penelitian ini dilakukan pada salah satu kampung tua yang terletak di Kota Malang. Pemilihan lokasi didapatkan dikarenakan salah satu kampung tua yang memiliki area bersejarah dengan kehidupan sosial yang masih mencerminkan masyarakat Jawa dengan adat istiadatnya.

Lokasi wilayah studi penelitiana terdapat pada Kampung Panggung, Kelurahan Mojolangu, Kecamatan Lowokwaru RW 9 dengan 4 RT. Berikut merupakan detail lokasi wilayah studi yang digunakan bahwa pada Kampung Panggung, lokasi wilayah penelitian terdapat 287 bangunan dengan fungsi yang berbeda, diantaranya rumah sewa/kost, perdagangan dan jasa. Pada Kampung Panggung terdapat 237 kepala keluarga, dengan sisa bangunan diantaranya merupakan kost. 


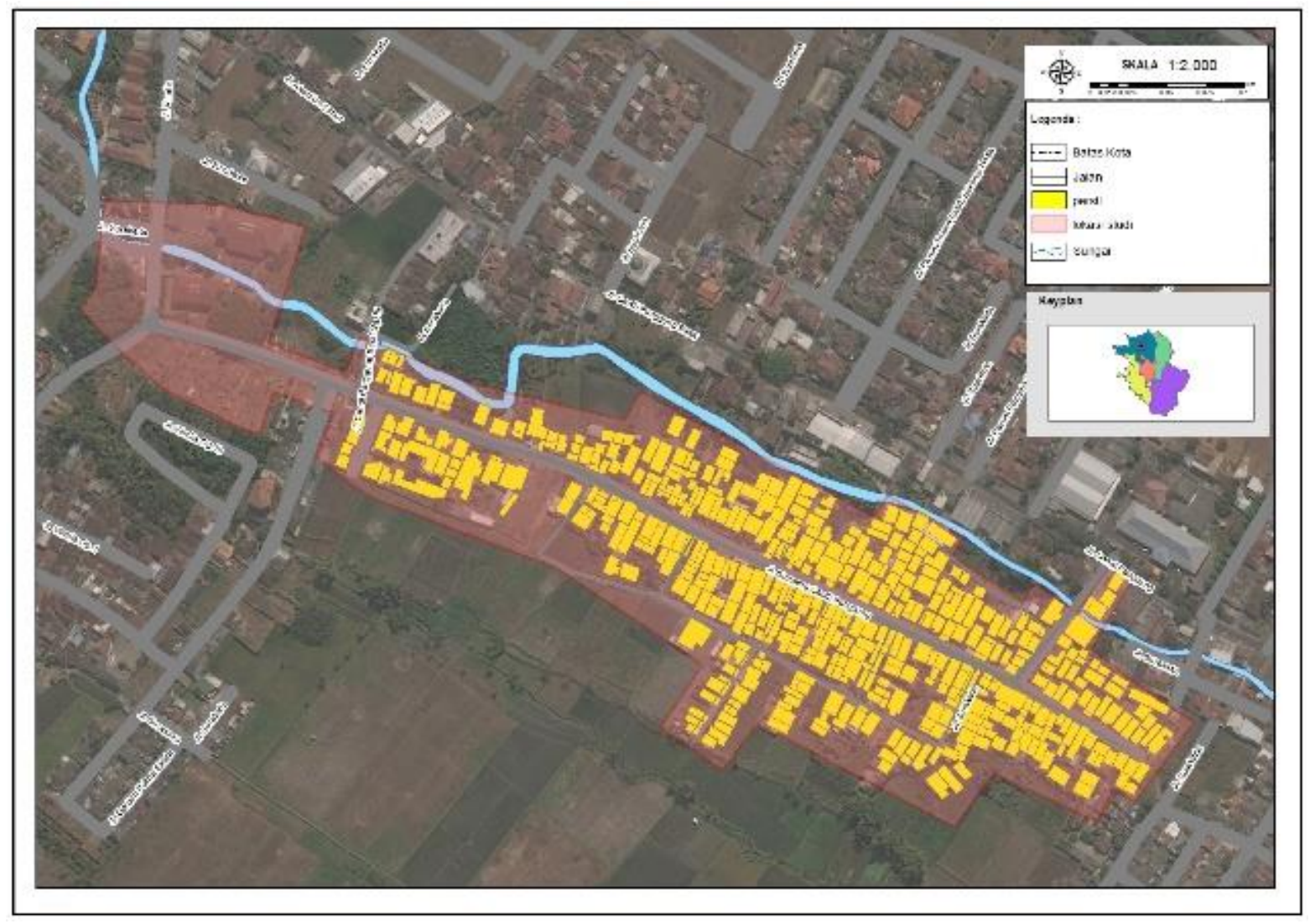

Gambar 1. Peta Wilayah Studi

\section{Populasi dan Sampel}

Populasi objek di Kampung Panggung meliputi jalan, halaman bersama dan bangunan rumah. Berikut populasi pada kondisi fisik. Populasi untuk jalan pada permukiman Kampung panggung hanya pada jalan utama yang terletak di tengah Kampung sebagai pusat utama jalan yang digunakan seluruh masyarakat. Populasi halaman bersama meliputi semua halaman yang berada di sekitar rumah pada lokasi penelitian. Populasi bangunan di permukiman Kampung Panggung terdiri dari 237 bangunan

Populasi subjek merupakan populasi masyarakat sebanyak 1.075 (295 jiwa) yang bertempat tinggal di Kampung Panggung, Kota Malang. Pada penelitian ini populasi masyarakat yang dimaksud ialah masyarakat yang mempunyai dan tinggal pada rumah di Kampung Panggung dengan tujuan untuk mengetahui karakteristik sosial budaya dan sejarah pada permukiman kampung, yang akan diolah pada bab pembahasan untuk dapat melihat pola permukiman di Kampung Panggung.

Sampel yang dipakai pada populasi objek berupa jalan utama yang berada pada tengah kampung, kelompok rumah beserta halaman lingkungannya. Pada popuasi subjek metode sampel yang digunakan dalam penelitian ini adalah purposive sample. Purposive sampling yaitu pengambilan sampel dengan menggunakan pertimbangan peneliti sendiri. Purposive sampling dilakukan dengan menetapkan kriteria tertentu sebagai dasar dalam menentukan sampel yang akan diambil, sehingga kemudian dilanjutkan dengan teknik quota sampling yang membagi sampel terpilih ke dalam sub grup berdasarkan faktor yang ada. Kriteria yang dipakai dalam penelitian ini yang pertama adalah bangunan yang dihuni selama dua generasi atau lebih, agar bisa mengidentifikasi siklus hidup penghuni dan pola perubahan aktivitas serta fisik bangunan. Kriteria yang kedua adalah bangunan yang masih difungsikan sebagai tempat tinggal atau fungsi lain yang dimungkinkan adanya aktivias didalamnya. Kriteria yang ketiga adalah memungkinkan dilakukannya observasi, utamanya berkenaan dengan pengambilan data langsung kepada pemilik bangunannya. Sedangkan kriteria terakhir adalah bangunan dengan keberadaan pintu butulan (yang masih memiliki pintu butulan atau yang pernah memiliki pintu butulan). 


\section{Variabel Penelitian}

Penelitian menggunakan teknik analisis deskriptif yaitu untuk mengidentifikasi bentukan pola permukiman serta interaksi sosial didalamnya. Dalam melakukan analisis tersebut, diperlukan beberapa varibel. Berikut merupakan variabel dalam penelitian.

Tabel 2. Variabel Penelitian

\begin{tabular}{clll}
\hline No. & Tujuan Penelitian & Variabel & Sub Variabel \\
\hline & & & Usia Bangunan \\
& & Status \\
& & Kepemilikan \\
Mengetahui dan & & Jenis Bangunan \\
menganalisis & & Fungis Bangunan \\
karakteristik pola & Pola & Bentuk Bangunan \\
\cline { 2 - 3 } 1. & permukiman di & Permuki & Tata Bangunan \\
Kampung & man & Permukiman \\
\cline { 2 - 3 } Panggung Kota & & Usia Bangunan \\
Malang & & Status \\
& & Kepemilikan \\
& & Sejarah \\
& & perkembangan \\
\hline Mengetahui dan & & \\
menganalisis & & Jenis Kegiatan \\
perwujudan & & Tujuan Kegiatan \\
interaksi sosial & Interaksi & Lokasi Kegiatan \\
dalam pola & Pelaku Kegiatan \\
permukiman di & Sosial & Waktu \\
Kampung & & Pelaksanaan \\
Panggung Kota & & Kegiatan \\
Malang & & \\
\hline
\end{tabular}

\section{Perwujudan Interaksi Sosial dalam Pola Permukiman di Kampung Panggung Kota Malang}

Pembentukan pola permukiman pada Kampung Panggung dapat dilihat berdasarkan kondisi fisik serta non fisik yang terdapat pada lokasi. Kondisi non fisik yang terdapat pada Kampung Panggung sebagai pembentuk pola permukimannya adalah berupa sejarah dan perkembangan permukimannya. Sejarah terbentuknya Kampung Panggung disebut bahwa nama "panggung" didapat dari sebuah legenda adanya sebuah pohon yang terletak di area pepunden. Tidak jelas jenis pohon apa sebenarnya, tingginya menjulang sekitar 15-20 $\mathrm{m}$, uniknya dari pohon tersebut batang langsung keluar daun-daunnya yang menyerupai daun kopi, sehingga oleh warga setempat disebut dengan 'wit kopen (kopi)' dan juga sering disebut "Pohon Kayu Tanjung", pada pucuk pohon terdapat sebuah cabang yang sering dikunjungi oleh burung perkutut dengan suara yang indah. Pohon tersebut seperti sebuah panggung untuk burung-burung tersebut. Sehingga dari legenda itulah, nama kampung atau desa ini disebut Kampung Panggung.

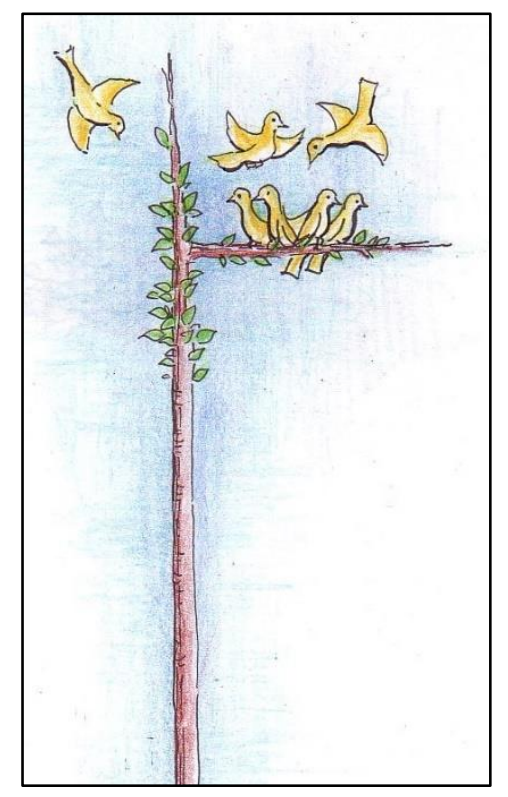

Gambar 2. Pohon "Wit Kopen"

Sedangkan nama candi, berasal dari nama tumpeng yang digunakan pada saat acara ritual bersih desa (barikan), yaitu 'tumpeng candi murup', bentuknya adalah berupa nasi tumpeng yang dikelilingi oleh obor (api), dan sepertinya merupakan sebuah candi yang diterangi oleh obor. Selain itu, di area pepunden juga ditemukan sebuah batu candi yang diduga sebagai sebuah situs atau artefak yang mungkin bisa digali dan dikaji lebih dalam. Dari perpaduan legenda desa tersebut, desa ini lebih dikenal dengan nama desa "Candi Panggung". Selain itu terdapatnya 'pepunden beji sari' atau juga biasa disebut 'pepunden banyu peres' yang merupakan salah satu peninggalan bersejarah di Kota Malang, Pepunden Beji Sari dari cerita atau legenda yang ada, merupakan 'petilasan' di jaman Kerajaan Singosari, karena dari cerita turun temurun warga bahwa dahulu Putri Ken Dedes pernah beristirahat sejenak di pepunden ini ketika melakukan perjalanan melalui melalui Kampung Candi Panggung, informasi lainnya adalah dari artefak yang ditemukan di area pepunden, bahwa batu pijakan yang digunakan untuk menuruni area sendang terbuat dari batu candi dengan ukuran cukup besar. Nama 'pepunden beji sari' menurut sesepuh kampung, memiliki arti 'beji' yaitu senjata dan 'sari' adalah inti. Menurut sesepuh desa arti dari 'beji sari' ini sendiri adalah tempat untuk mengasah senjata, mengasah senjata dalam hal ini memiliki pengertian bukan sebagai mengasah senjata yang sebenarnya, namun berupa senjata diri atau senjata hati atau yang biasa disebut sebagai 'aji-aji'. Pepunden beji sari dahulu biasa digunakan untuk pertapa dan mencari pertahanan diri. 


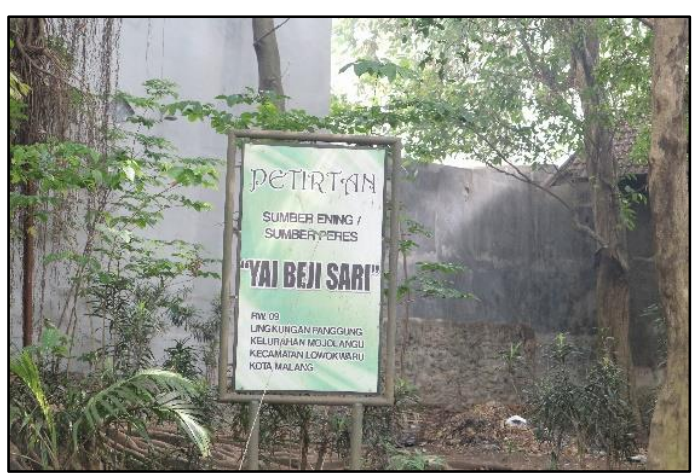

Gambar 3. Petirtan Beji Sari

Berkaitan dengan makna kultural, bukan haya Pepunden Beji Sari saja yang terdapat pada Kampung Panggung, namun juga terdapat dua sumber air lainnya. Pada bagian timur koridor Kampung Panggung terdapat sebuah belik (sumber air) Ngaglik yang mana berasal dari Kali Manak dan pada bagian tengah kampung terletak belik Lamer. Menurut penelitian sebelumnya (Handajani, 2006) Kali Manak pada Kampung Panggung merupakan sebuah sungai yang melintasi Kampung, dikarenakan terdapat mitos yang ada secara turun temurun bahwa dahulu jika ada yang baru melahirkan biasayan setelah melahirkan akan dimandikan di sumber air yang berada pada sungai tersebut. Begitupula dengan bayi yang berusia tujuh bulan biasanya masyarakat Jawa mengadakan acara 'tedhak siti' atau turun tanah dan bayi tersebut dibawa ke sungai tersebut untuk dimandikan. Tradisi ini sudah mulai berkurang, disebabkan karena kondisi air sungai yang sudah mulai surut dan semakin keruh.

Belik Lamer terletak di tengah kampung, pada awal permukiman sumber air tersebut digunakan sebagai keperluan sehari-hari masyarakat kampung. Hal ini berhubungan dengan perkembangan kampung, dikarenakan awal pembetukan permukiman berawal dari tengah desa yaitu rumah milik Tarinah. Permukiman berkembang pada tengah kampung dengan memanfaatkan sumber mata air yang ada pada tengah kampung, dan kampung berkembang ke arah timur dan barat kampung.

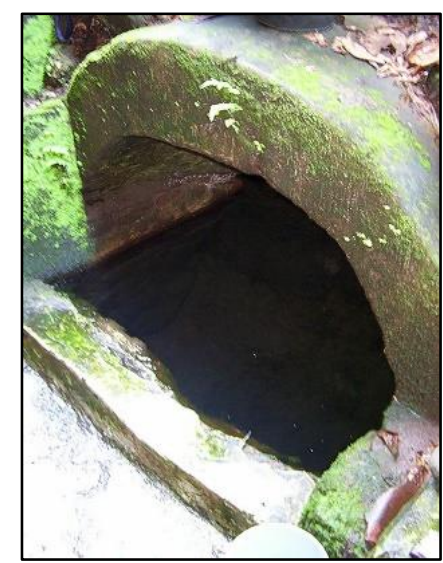

Gambar 4. Belik Lamer

Berdasarkan hasil survei menurut sesepuh kampung, makna yang dapat diambl dari sumber air tersebut adalah bahwa Belik Ngaglik merupakan simbol kelahiran, sedangkan Belik lamer adalah simbol penghidupan dan pepunden Beji Sari merupakan simbol kematian dengan arah pergerakan dari Timur ke Barat, yang dapat dianalogikan seperti muncul dan tenggelamnya matahari, ataupun juga seperti kehidupan manusia bahwa berawal dari kelahiran dan berakhir kematian.

Perkembangan permukiman berdasarkan kondisi fisik buatan pada Kampung Panggung dapat berupa jalan serta sungai sebagai pembatas antara Kampung Panggung dengan permukiman lainnya. Pembentukan pola permukiman berdasarkan non fisik juga dapat dilihat melalui adat dan kebudayaan serta temuan pintu butulan yang membentuk adanya interaksi yang terjalin antara kelompok rumah satu dengan kelompok rumah lainnya. Pembentukan pola permukiman mikro berdasarkan hubungan kekerabatan terbagi menjadi 30 kelompok rumah.

Selain pembentukan kelompok rumah berdasarkan kelompok keluarga, terdapat fitur pola permukiman yang terjadi berdasarkan sejarah kampung. Fitur yang terdapat pada Kampung Panggung terdapat 4 jenis, yaitu pawonan, buk, pohon belimbing, dan pintu butulan. Fitur yang pertama, yaitu pawonan sudah banyak hilang dan tergantikan oleh kompor gas, dikarenakan menurut masyarakat kurang efektif dan kurang cepat untuk digunakan memasak. 


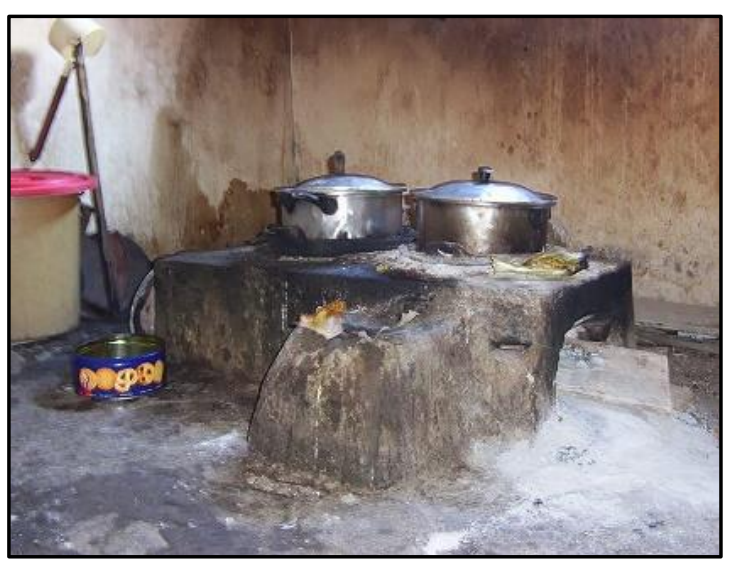

Gambar 5. Pawonan

Fitur selanjutnya adalah 'buk' yaitu berupa pagar pendek depan rumah. Fitur ini juga sudah tersisihkan dan tergantikan dengan pagar besi tinggi. Selain itu juga menghilangkan ruang bersama yang dahulu digunakan untuk berkumpul pada saat acara adat budaya.

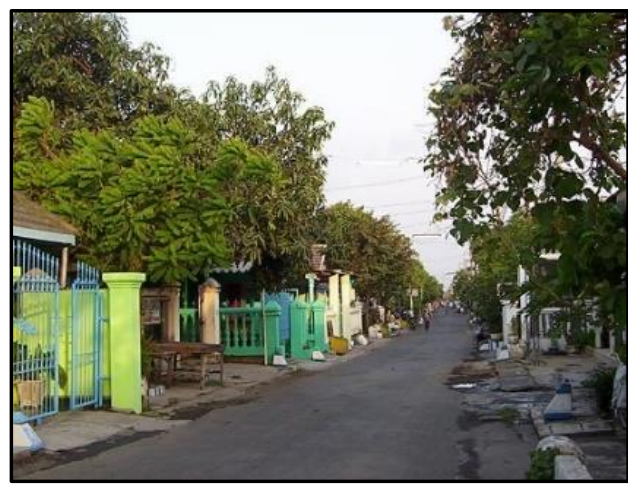

Gambar 6. Pohon belimbing

Fitur selanjutnya adalah pohon belimbing. Pohon belimbing dilambangkan sebagai rukun islam, pada tahun 1920-2006 pohon ini masih banyak terdapat pada Kampung Panggung. Namun saat ini pohon belimbing sudah jarang ditemukan, disebabkan karena kebutuhan ruang masyarakat semakin tinggi, sehingga menghilangkan halaman depan yang terdapat pohon belimbing dan pagar buk, karena itu juga mengurangi ruang bersama yang terdapat diantaranya.

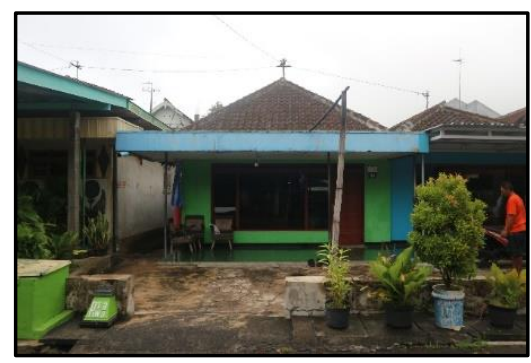

Gambar 7. Pagar 'buk'

Fitur selanjutnya adalah pintu butulan. Pintu butulan masih banyak terdapat pada Kampung Panggung, pintu ini digunakan sebagai penghubung antara rumah, dan juga digunakan sebagai pennghubung interaksi sosial masyarakat.

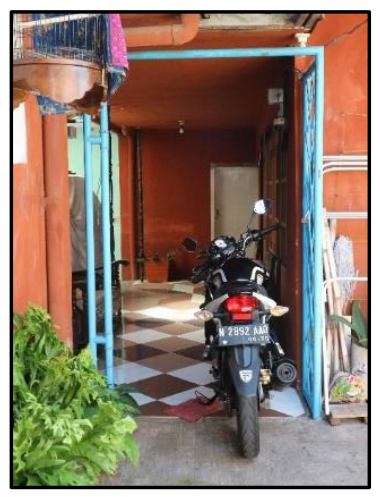

Gambar 8. Pintu butulan

Berdasarkan hasil analisis synchronic / diachronic, dan alisis family tree diperoleh bentukan dan kelompok-kelompok rumah yang terbentuk berdasarkan hubungan kekerabatan dan family tree. 


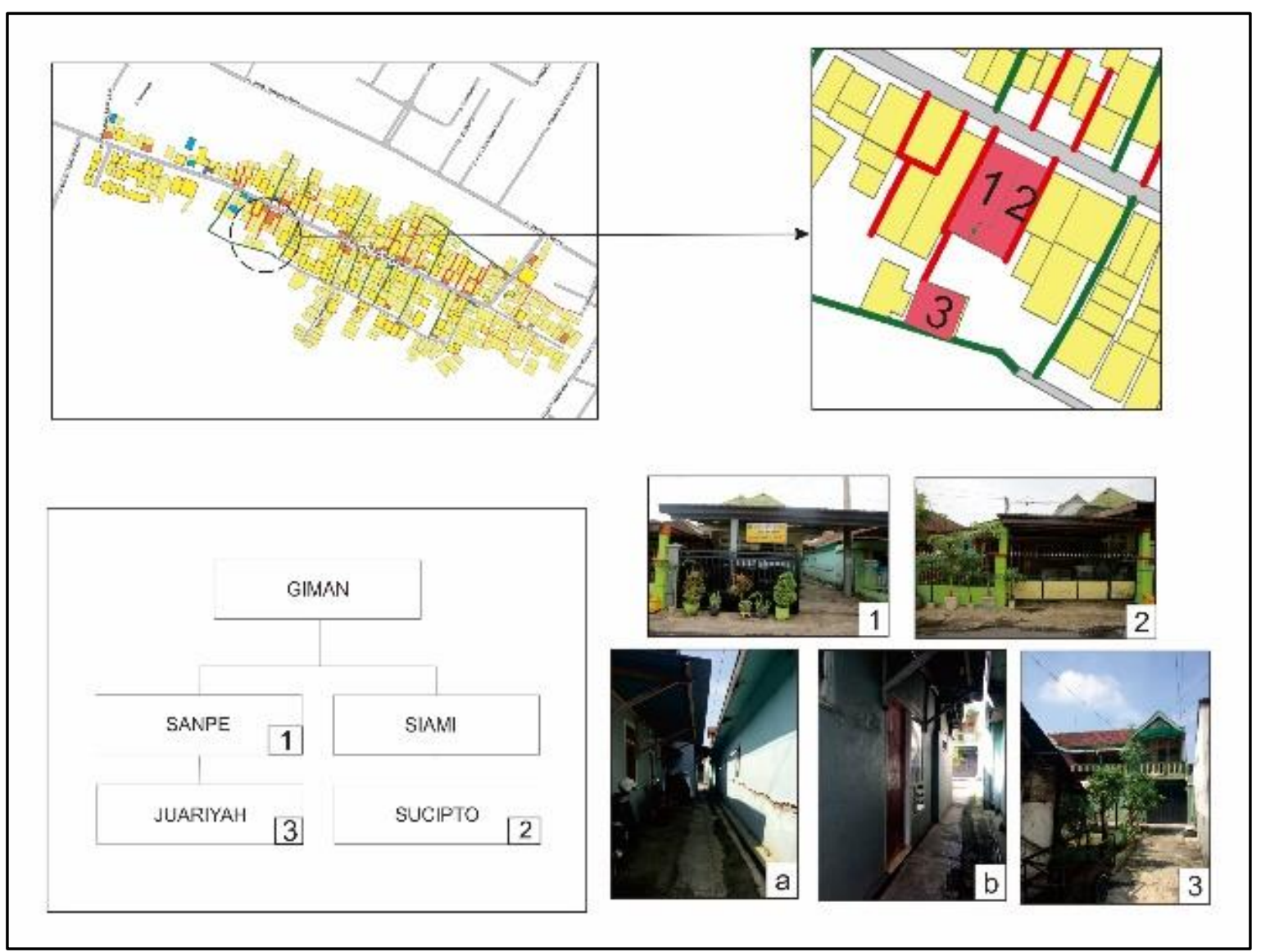

Gambar 9. Hubungan kekerabatan dan kelompok

Berdasarkan hasil survei, diperoleh 30 kelompok rumah keluarga, yang kemudian dapat diolah untuk menemukan bentukan pola permukiman mikro pada Kampung Panggung. Pada Pola pengelompokan linier mendominasi pada Kampung Panggung, pada awal perkembangan perumahan, pola linier cenderung berderet sepanjang jalan utama kampong, namun karena semakin menyempitnya lahan yang ada sehingga berkembanglah pola linier yang mengarah ke bagian dalam jalan utama kampung. Pola linier berderet di sepanjang jalan cenderung terjadi ketika ketersediaan lahan masih cukup luas, sedangkan bagian belakang digunakan untuk lahan pertanian ataupun perkebunan. Pada pola linier berderet sepanjang jalan terdapat 18 pola kelompok rumah yang terbentuk.

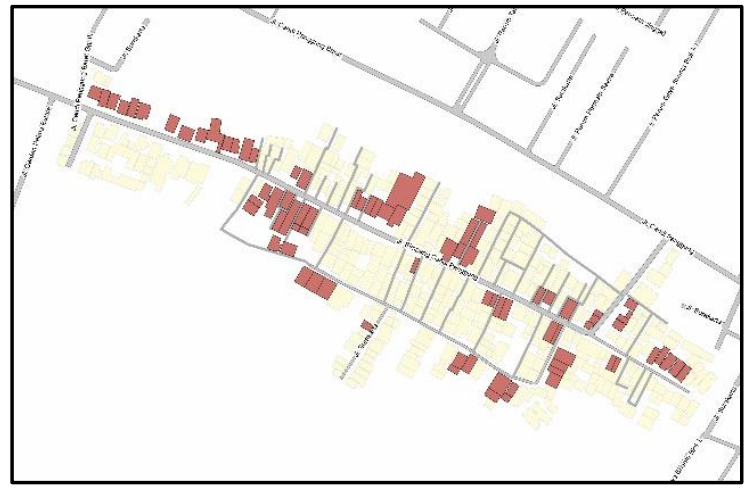

Gambar 10. Pola linier berderet kesamping

Sedangkan pada pola linier berderet kearah dalam jalan dapat disebabkan oleh beberapa alasan yaitu keterbatasan lahan hak waris, sehingga perkembangan rumah menjadi berderet kearah dalam jalan selain itu adanya perubahan mata pencaharian dari bertani menjadi pedagang sehinga lahan bagian belakang rumah tidak lagi dipergunakan sebagai lahan pertanian dan cenderung digunakan untuk lahan rumah tinggal. Pada pola linier berderet kearah dalam jalan terdapat 5 kelompok rumah. 


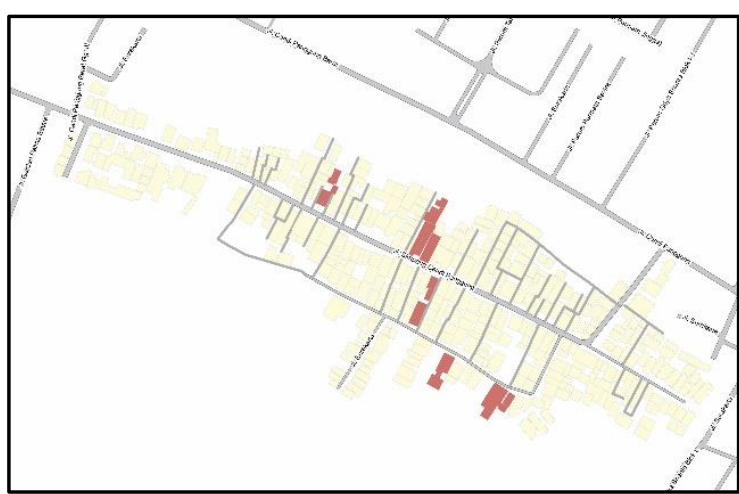

Gambar 11. Pola linier berderet kedalam

Pola pengelompokan secara terpusat juga terdapat pada Kampung Panggung. Pada pola terpusat biada terdapat ruang bersama, yaitu biasanya terdapat pada bagian depan, samping atau belakang rumah. Hubungan yang terjalin pada kelompok pola terpusat akan lebih terlihat pada pola ini. Pada pola terpusat terdapat 7 kelompok rumah.

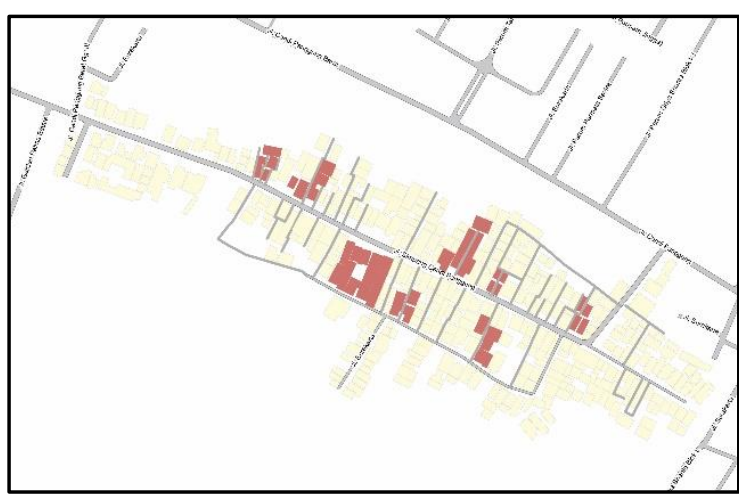

Gambar 12. Pola terpusat

Hubungan kekerabatan yang ditemukan pada Kampung Panggung terdapat 10 kelompok keluarga. Kelompok keluargayang terbentuk adalah kelompok keluarga Tarinah, kelompok keluarga Supi, Kelompok Keluarga Sarimun, kelompok Keluarga Warinten, kelompok Keluarga Sriatun, kelompok Keluarga Kadir, kelompok Keluarga Gimo, kelompok Keluarga Markam, kelompok Keluarga Taip, dan kelompok Keluarga Paidi.

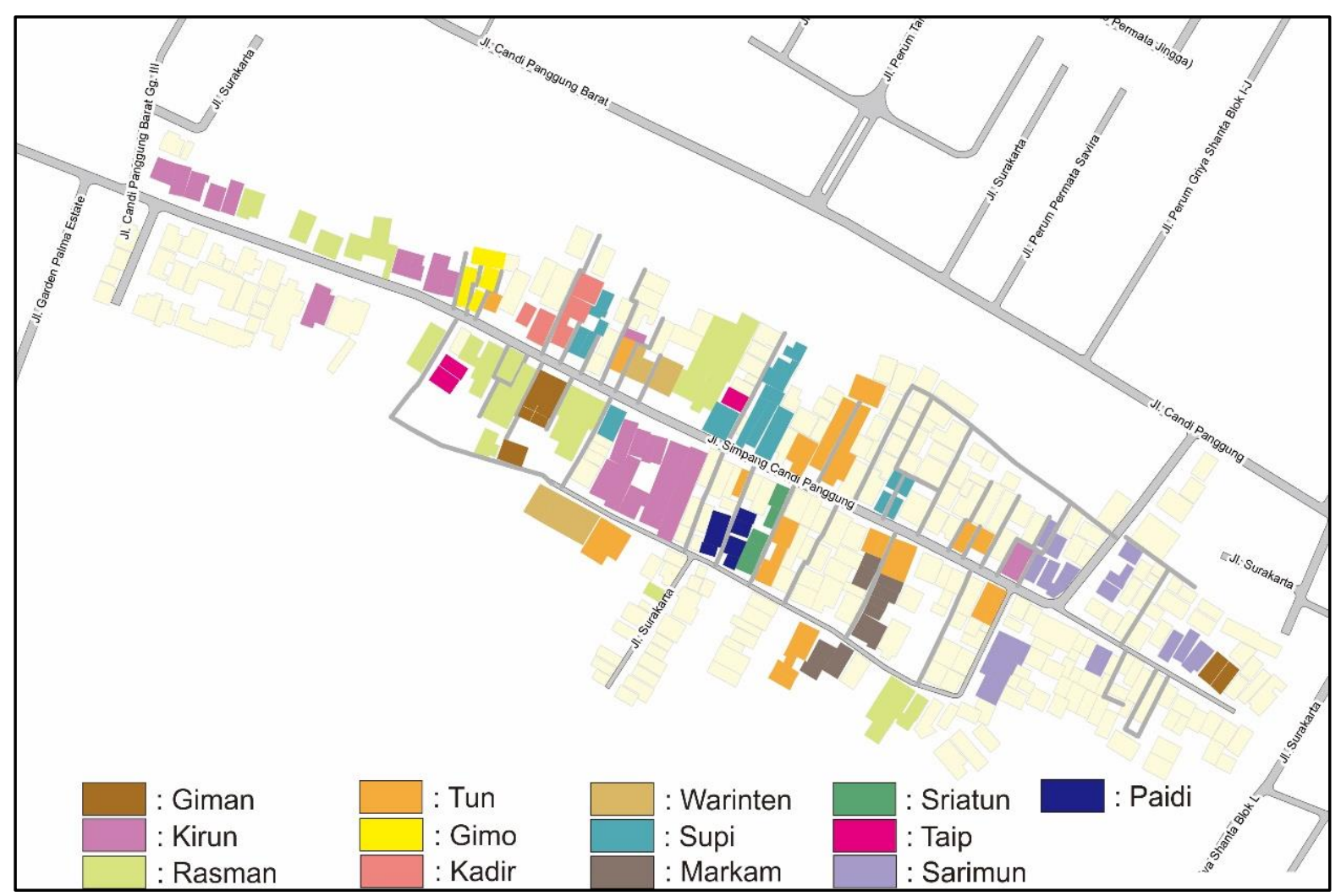

Gambar 13. Hubungan kekerabatan Tarinah

Berdasarkan 10 kelompok keluarga (Giman, Kirun, Rasman, Tun adalah kelompok keluarga Tarinah) didapatkan melalui hasil olahan data sebelumnya dapat diketahui bahwa hubungan interaksi sosial yang terjadi pada setiap kelompok rumah adalah berupa 16 hubungan asosiatif, 15 hubungan akomodasi, serta 1 konflik. 


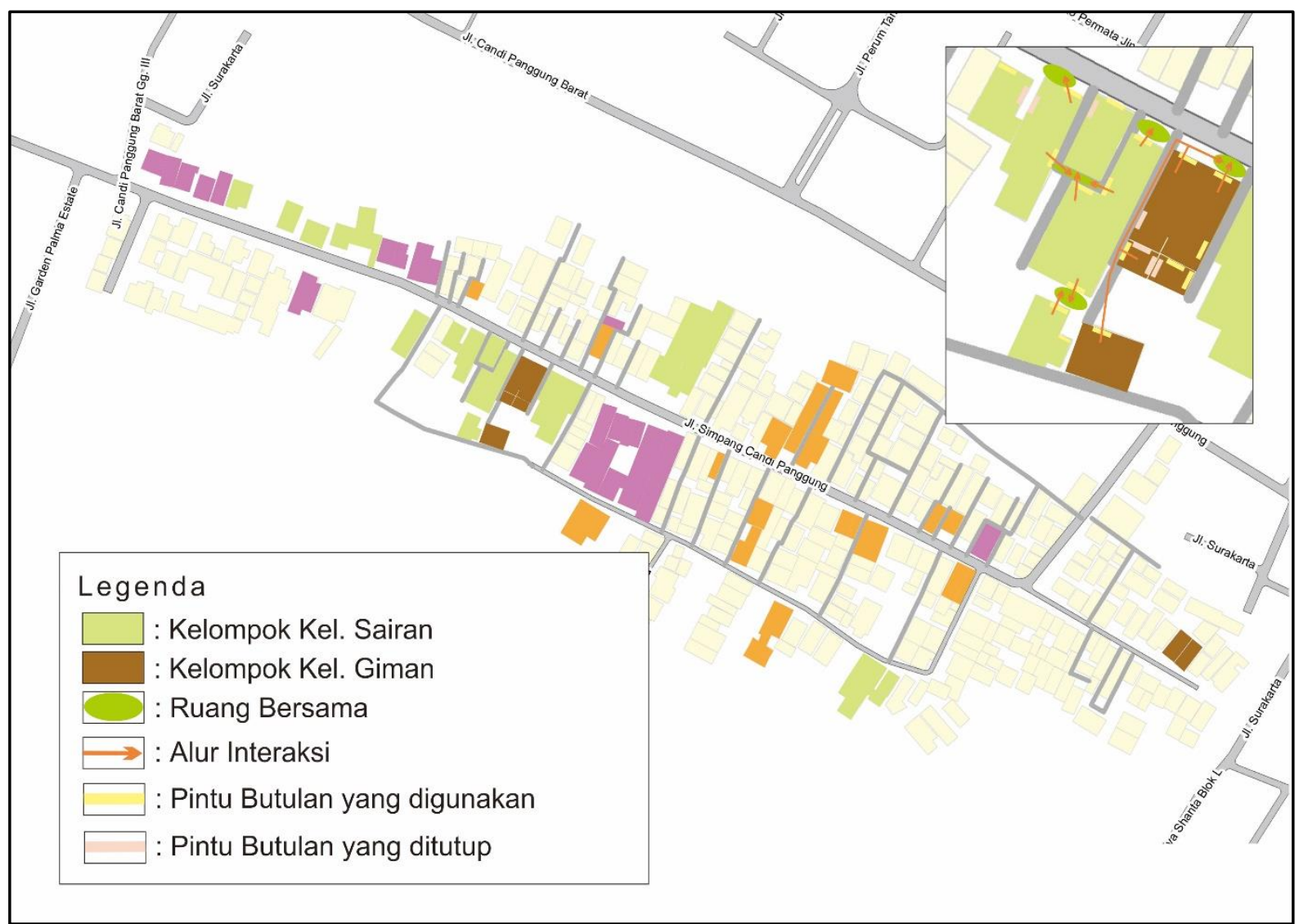

Gambar 14. Interaksi dan kelompok rumah keluarga Tarinah

\section{KESIMPULAN}

Berdasarkan hasil dari penelitian perwujudan interaksi sosial dalam Pola Permukiman Kampung Panggung adalah sebagai berikut.

Pembentukan pola permukiman pada Kampung Panggung dapat dilihat berdasarkan kondisi fisik serta non fisik yang terdapat pada lokasi. Kondisi fisik buatan pada Kampung Panggung dapat berupa jalan serta sungai sebagai pembatas antara Kampung Panggung dengan permukiman lainnya. Pembentukan pola permukiman berdasarkan non fisik juga dapat dilihat melalui adat dan kebudayaan serta temuan pintu butulan yang membentuk adanya interaksi yang terjalin antara kelompok rumah satu dengan kelompok rumah lainnya.

Berdasarkan hasil analisis synchronic/diachronic ditemukan bahwa terdapat beberapa perubahan fitur yang terjadi pada Kampung Panggung. Perubahan yang pertama adalah menghilangnya fitur pawonan dikarenakan kebutuhan ruang yang lebih dan juga sudah memudarnya nilai budaya yang tertanam pada masyarakat Kampung Panggung. Pawonan yang dahulunya digunakan untuk memasak makanan secara banyak yang akan digunakan untuk hajatan sudah berubah karena sudah tidak efektif, dan masyarakat merasa menggunakan kompor bakar tungku lebih lama daripada menggunakan kompor gas.

Perubahan yang kedua adalah pada area depan rumah masyarakat Kampung Panggung, sudah tidak terdapat fitur pohon belimbing dan pagar ' $b u k$ '. Menghilangnya fitur ini disebabkan juga karena meningkatnya kebutuhan ruang masyarakat kampung, dan berubahnya fungsi ruang yang pada awalnya area depan rumah warga digunakan sebagai ruang bersama, berubah menjadi bangunan berupa sarana perdagangan maupun jasa. Hal ini berhubungan dengan menipisnya minat masyarakat untuk tetap berpegang teguh pada nilai budaya yang berkembang sebelumnya. Selain itu perubahan ini juga menimbulkan perubahan pada interaksi sosial yang terjadi pada masyakaran Kampung Panggung. Perubahan yang terjadi diakibatkan berkurangnya area ruang bersama yang digunakan masyarakat untuk berkumpul yang pada saat itu berada pada area depan rumah.

Fitur yang masih ada hingga saat ini adalah pintu butulan, hal ini ada dikarenakan masih terdapat beberapa masyarakat yang merasa bahwa pintu butulan merupakan aspek penting dalam menyambung hubungan antara satu dengan lainnya. Pintu butulan sebagai penyambung antara rumah satu dengan rumah 
lainnya yang memudahkan akses masyarakat untuk berinteraksi.

Berdasarkan hasil analisis melalui analisis family tree, syncronich/ diachronic dan behavior setting dapat ditemukan bahwa terdapatnya perubahan interaksi sosial yang disebabkan oleh perubahan fungsi ruang. Terdapat 237 bangunan yang terdapat pada Kampung Panggung, dengan fungsi sebagai rumah tingga, rumah sewa/kost, perdagangan dan jasa. Pola permukiman yang terdapat di Kampung Panggung dapat dibedakan berdasarkan bentukan pola mikro yang ada yaitu berupa pola linier (menyamping searah dengan jalan atau kedalam badan jalan) dan pola terpusat. Ketiga tipe tersebut didapatkan berdasarkan hasil overlay peta kondisi fisik dan non fisik yang memiliki hubungan satu sama lain dengan keterkaitannya berupa tata bangunan kekerabatan serta adanya temuan pintu butulan pada Kampung Panggung. Pada pola linier menyamping kampung, terdapat 18 kelompok rumah. Sedangkan pola linier berderet kearah dalam kampung terdiri dari 5 kelompok rumah. Pola terpusat terdiri dari 7 kelompok rumah.

Interaksi yang terbentuk pada Kampung Panggung terbagi menjadi empat jenis yaitu Asosiatif, Akomodasi, Asimilasi, dan Konflik. Interaksi ini dibagi berdasarkan perbedaan antara jenis kegiatan, tujuan kegiatan, pelaku kegiatan, lokasi kegiatan, dan waktu pada saat kegiatan. Pembagian interaksi ini didapatkan berdasarkan hasil survei pada seluruh populasi dan kelompok rumah pada Kampung Panggung.

Berdasarkan interaksi dan pola permukiman yang terbentuk, ditemukan berbagai kekerabatan yang terjalin dalam hubungan sedarah maupun perkawinan. Hubungan kekerabatan ini membentuk adanya sepuluh kelompok besar di Kampung Panggung. Perubahan interaksi sosial pada Kampung Panggung sebagian besar disebabkan oleh adanya perubahan fungsi pada bangunan pada awal tahun 2005 hingga saat ini, yaitu disebabkan semakin banyaknya bangunan yang beralih fungsi menjadi kost atau rumah sewa dikarenakan menurut masyarakat sekitar memiliki pemasukan yang menghasilkan.

\section{DAFTAR PUSTAKA}

Budiharjo, E. (1999). Arsitektur Pembangunan dan Konservasi. Jakarta: Djambatan.

Handajani, R. P. (2006). Fenomena Pintu Butulan di Kampung Candi Panggung Kota Malang. Malang: Universitas Brawijaya.

Rapoport, A. (1969). House Form and Culture. Englewood Cliffs: Prentice-Hall. 